\title{
Some English Stress Mistakes and Solutions - A Phonetic Experimental Research on Vietnamese Students
}

\author{
Tran Thi Thanh Dieu \\ Faculty of English Linguistics and Literature, University of Social Sciences and Humanities, Viet Nam National University, Ho Chí Minh City, \\ Vietnam
}

Email address:

thdieu2003@yahoo.com, thanhdieutt@hcmussh.edu.vn

\section{To cite this article:}

Tran Thi Thanh Dieu. Some English Stress Mistakes and Solutions - A Phonetic Experimental Research on Vietnamese Students. International Journal of Language and Linguistics. Vol. 5, No. 2, 2017, pp. 39-49. doi: 10.11648/j.ij11.20170502.13

Received: February 26, 2017; Accepted: March 10, 2017; Published: March 27, 2017

\begin{abstract}
The combination of phonological knowledge with rhythm and English stress rules is one of the solutions for English stress problems facing Vietnamese students. From the phonetic experiment, some types of stress mistakes made by Vietnamese students were discovered. The hypothesis is that the English Rhythmic patterns and English stress rules will help students to solve their stress problems. However, the English stress rules are so complicated. Therefore, based on the main rhythmic pattern, the key for stress rules has been raised to simplify the way to recognize stressed syllables. The final target is to help Vietnamese students identify English words through different ways of stress placement in order to increase their pronunciation ability as well as catching the main idea in the conversation to improve their communicative skill in English.
\end{abstract}

Keywords: English Rhythmic Pattern, Complex Rhyme, Heavy Syllable, English Stress Rules, Phonetic Experiment

\section{Introduction}

No one can deny that every language in the world has its own characteristic speech rhythm. English tends to be a stress-timed language with rhythmic patterns based on a fairly regular recurrence of stressed syllables [3]. However, Vietnamese tends to give equal weight to each syllable $[4,29,30]$. As a result, many students often use the Vietnamese rhythmic pattern when speaking English. In addition, Vietnamese language has mono-syllabic words while English words are multi-syllabic. Therefore, they are the main reasons leading to stress problems facing Vietnamese students.

To solve this problem, it is important for students to know the different rhythmic patterns between Vietnamese and English. Moreover, the English stress rules are so complicated that it is not easy for Vietnamese students to recognizer stress syllables in English multi-syllabic words. Therefore, the paper aim to simplify the English stress rules mainly based on the English rhythmic characteristics and types of English stress mistakes recognized through phonetic experiment made by Vietnamese students.

\section{Methodology}

The research was conducted for twenty-four weeks from January 2012 to June 2012 with six weeks for preparation and choosing population, twelve weeks for phonetic experiment, and the last six weeks for data analysis. The method used in the research is the comparative strategy based on the prosodic analysis of Rhythmic patterns between English and Vietnamese, as well as the combination of quantitative approach and phonetic experimental approach to find out students' stress mistakes and solutions.

The word samples were recorded from the 'Oxford Advanced Learner Dictionary' 'Cambridge Advanced Learner Dictionary' and 'Multi-Dictionary version 9.0 HuyBiên 2008', called standard pronunciation (Cáchphátâmchuẩn $=\mathrm{CPAC}$ ) or RP (Received pronunciation) and from the population (students), called investigating samples (Mẫukhảosát = MKS) or $\mathrm{T}$ (Token). The data was analyzed and illustrated by SPEECH ANALYZER (Copyright (C) 1996-2007 by SIL International) and PRAAT 5.05.12. (copyright @ 1992-2008 by Paul Boersma and David Weenink). 


\section{Data Analysis and Finding}

\subsection{Comparison Between English and Vietnamese Rhythmic Patterns}

"English is a Stress-timed language, with the rhythmic pattern based on the regular repetition of the stressed syllables. Whereas, Vietnamese tends to have the equal syllable to form the Rhythmic pattern of the Syllable-timed language, with the syllables having the equal intensity" [[3]]. Therefore in the paper "A case study of solutions to some stress mistakes made by Vietnamese students - a phonetic experimental research" by Dr. Tran Thi Thanh Dieu, a table of comparison between the English and Vietnamese rhythmic patterns has been summarized as follows [[6]].

Table 1. Comparison of the English and Vietnamese Rhythmic Patterns.

\begin{tabular}{lll}
\hline & $\begin{array}{l}\text { ENGLISH RHYTHMIC } \\
\text { PATTERN }\end{array}$ & $\begin{array}{l}\text { VIETNAMESE } \\
\text { RHYTHMIC PATTERN }\end{array}$ \\
\hline \multirow{3}{*}{$\begin{array}{l}\text { Type of } \\
\text { language }\end{array}$} & $\begin{array}{l}\text { Stress-timed language, with } \\
\text { the rhythmic pattern based } \\
\text { on the regular repetition of } \\
\text { the stressed syllables }\end{array}$ & $\begin{array}{l}\text { Syllable-timed language, } \\
\text { with the syllables having } \\
\text { the equal intensity, }\end{array}$ \\
Pattern & $\{\mathrm{F}=[\mathrm{S} \mathrm{W}]\}$ & $\{\mathrm{N}=[\mathrm{A}]\}=\{\mathrm{R}==[\mathrm{S}]\}$ \\
$\begin{array}{l}\text { Meaning of the } \\
\text { abreviation }\end{array}$ & $\mathrm{F}=$ Foot & $\mathrm{N}=$ nhịp $(=$ Rhythm) \\
& $\mathrm{S}=$ strong $\mathrm{W}=$ weak & $\mathrm{A}=$ âm tiết (= syllable) \\
\hline
\end{tabular}

The foundation of the English rhythmic pattern is the existence of the 2 types of syllable: heavy and light syllable. A light syllable contains only a short vowel in the rhyme, with no coda, as in the first syllable of the word "about" because onsets are entirely irrelevant to the calculation of syllable weight [[18]]. If a syllable has a complex rhyme, then it is heavy; and complexity of rhyme can be achieved in two different ways. First, a heavy syllable may have a short vowel, but one or more coda consonants, as in the word "bet, best". Second, it may have a branching nucleus, consisting of a long vowel or diphthong; such a syllable will be heavy whether it also has a bled coda, as the second syllable of the word [chor ale] and as it put by the Cambridge advance learner dictionary - third edition "when a word or syllable is pronounced with greater force than other words in the same sentence or other syllables in the same word, it is stressed", as well as Fry $(1955,1958)$ 's identified the intensity over the syllable as a possible acoustic correlate of stress differences.

\subsection{Phonetic Experiment for Mistakes Recognization and Solutions}

\subsubsection{Phonetic Experiment Proving the Mistakes on English Word Stress Made by Vietnamese Students}

A spectrogram as the one below is created by displaying all of the spectra computed from the speech waveform together. The vertical axis in a spectrogram represents frequency, with 0 $\mathrm{Hz}$ at the bottom. The lines visible in the spectrogram on this page each represent $1000 \mathrm{~Hz}$ along the frequency axis, so that the spectrogram contains $8000 \mathrm{~Hz}$ in total. All of the spectra computed by the Fourier transform are displayed parallel to this vertical or $y$-axis. The horizontal axis represents time; as we move right along the $\mathrm{x}$-axis we shift forward in time, traversing one spectrum after another. Spectrograms are normally computed and kept in computer memory as a two-dimensional array of acoustic energy values. For a given spectrogram $S$, the strength of a given frequency component $f$ at a given time $t$ in the speech signal is represented by the darkness or color of the corresponding point $S(t, f)$. Therefore, $\mathrm{RP}=\mathrm{CPAC}$ (Cáchphátâmchuẩn: received pronunciation /standard pronunciation) and IS = MKS (Mẫukhảosát: token/ investigated sample) of many words of all types were recorded and investigated by phonetic experiment providing the result, in which the word [chorale] has been chosen for illustration as the following spectrogram figures.

\section{ĐỐ CHIÊU CƯờnG Độ ÂM TIÊT NHẬN TRỌNG ÂM GIỮA CPAC VÀ MKS}

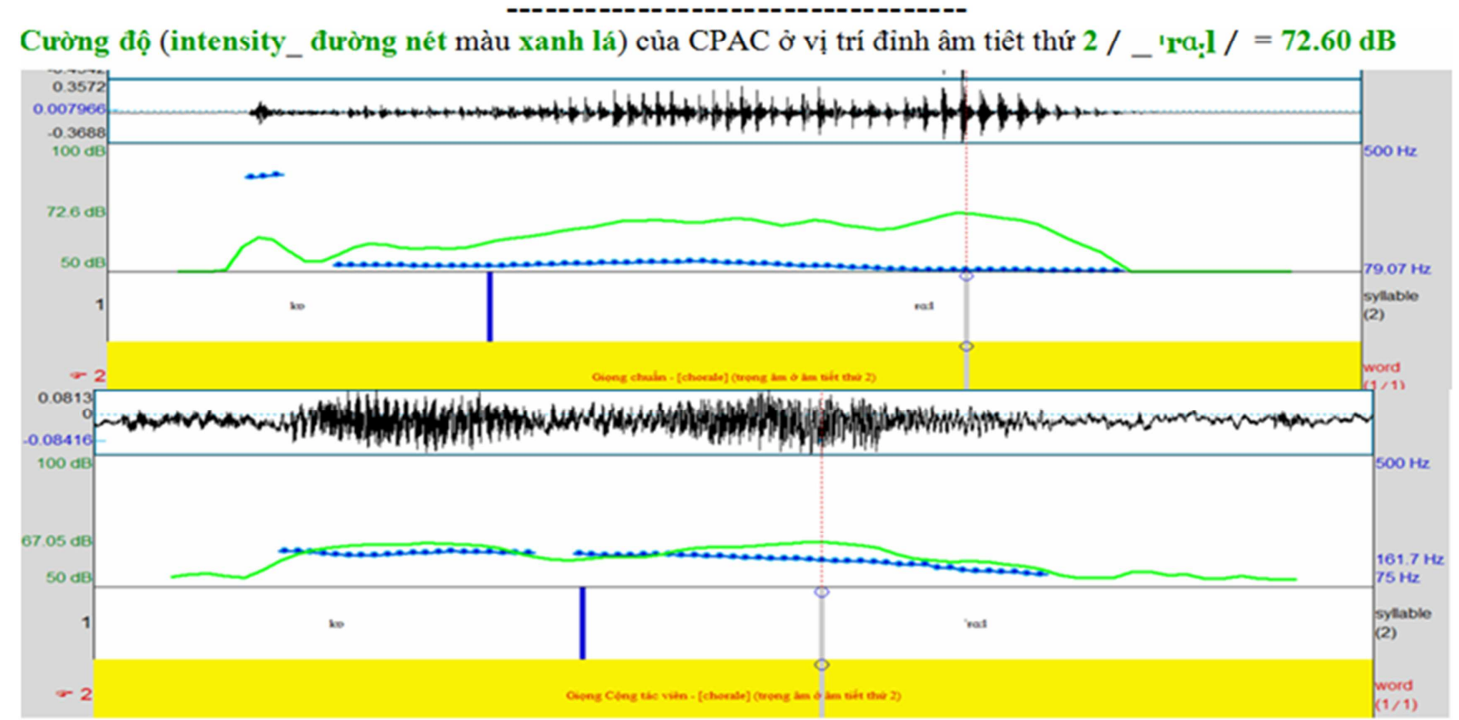

Cường độ (intensity_đường nét màu xanh lá) cao nhất MKS đạt $67.05 \mathrm{~dB}$ ở vị trí âm tiết thứ 2 / _ 'ra:1 /

Figure 1. Spectrogram of the Pitch and Intensity comparison between RP and IS. 
Table 2. Comparison of the Intensity and Pitch between RP and IS.

\begin{tabular}{llll}
\hline \multicolumn{2}{l}{ MAXIMUM NUMBER } & RP & IS \\
\hline \multirow{2}{*}{ INTENSITY } & SYLLABLE 1 & $60.66 \mathrm{~dB}$ & $66.24 \mathrm{~dB}$ \\
\multirow{2}{*}{ PITCH } & SYLLABLE 2 & $72.60 \mathrm{~dB}$ & $67.05 \mathrm{~dB}$ \\
& SYLLABLE 1 & & $183.7 \mathrm{~Hz}$ \\
\hline
\end{tabular}

As it put by the Cambridge advance learner dictionary third edition "when a word or syllable is pronounced with greater force than other words in other syllables in the same word, it is stressed", as well as Fry $(1955,1958)$ 's identified the intensity over the syllable as a possible acoustic correlate of stress differences, according to the number in the table and the spectrogram figures above, the intensity of RP $=\mathrm{CPAC}$ at the first syllable peak is $60.6 \mathrm{~dB}$ and at the second syllable peak is $72.60 \mathrm{~dB}$, therefore, we can have the conclusion that $\mathrm{RP}$ pronounced with a greater energy at the second syllable than at the second syllable $(72.60 \mathrm{~dB}-60.66 \mathrm{~dB}=12.06 \mathrm{~dB})$ and made the English rhythm pattern as $\{\mathrm{F}=[\mathrm{S} \mathrm{W}]\}$. Whereas the intensity of IS $=$ MKS at the first syllable peak is $66.24 \mathrm{~dB}$ and at the second syllable peak is $67.05 \mathrm{~dB}$, nearly the same intensity at the peak of the stressed and un stressed syllable $(67.05 \mathrm{~dB}-66.24 \mathrm{~dB}=0.81 \mathrm{~dB})$, which is a serious mistake caused by the influence of Vietnamese mother tongue, called interfering mistake in language with the Vietnamese rhythmic pattern as $\{\mathrm{N}=[\mathrm{A}]\}$. In addition, the pitch can't be used as the cue identifying stress syllable but just shows the accent type of the speakers.

To find out the types of English stress mistake made by Vietnamese students, 12 groups of IS from the Northern, Central and Southern of Vietnam have been recorded their pronunciation of the all kinds of English words, as follows.

- Simple words: multi-syllabic words without affix of Noun, Adjective, Verb.

- Complex words: multi-syllabic words with affix.

- Compound words: with 2 roots.

The result of the disyllabic word [chorale] pronounced by 12 groups of IS is used to illustrated the 3 types of English stress mistake made by Vietnamese students.

Table 3. Intensity and Pitch mean of RP and IS in the phonetic experiment.

\begin{tabular}{|c|c|c|c|c|c|c|c|}
\hline \multirow{2}{*}{ No } & \multirow{2}{*}{ Mistake-type Group } & \multicolumn{3}{|c|}{ Intensity mean } & \multirow{2}{*}{\multicolumn{2}{|c|}{$\begin{array}{l}\text { Mistake-type and the number of } \\
\text { IS in every group/ } 100\end{array}$}} & \multirow{2}{*}{$\begin{array}{l}\text { Pitch Difference } \\
\text { mean }\end{array}$} \\
\hline & & Syllable 1 & Syllable 2 & Difference & & & \\
\hline \multicolumn{2}{|c|}{$\mathrm{CPAC} / \mathrm{RP}$} & $62.90 \mathrm{~dB}$ & $72.60 \mathrm{~dB}$ & $9.70 \mathrm{~dB}$ & EXACT & \multirow{5}{*}{$33.33 \%$} & $107 \mathrm{~Hz}$ \\
\hline 1 & T_9 & $66.51 \mathrm{~dB}$ & $67.06 \mathrm{~dB}$ & $0.55 \mathrm{~dB}$ & A & & $183.7 \mathrm{~Hz}$ \\
\hline 2 & T/MKS_12 & $69.13 \mathrm{~dB}$ & $70.03 \mathrm{~dB}$ & $0.9 \mathrm{~dB}$ & A & & $189.4 \mathrm{~Hz}$ \\
\hline 3 & T_7 & $62.14 \mathrm{~dB}$ & $65.52 \mathrm{~dB}$ & $3.38 \mathrm{~dB}$ & A & & $176.5 \mathrm{~Hz}$ \\
\hline 4 & T_5 & $62.21 \mathrm{~dB}$ & $65.25 \mathrm{~dB}$ & $3.04 \mathrm{~dB}$ & A & & $123.5 \mathrm{~Hz}$ \\
\hline 5 & $T_{-} 10$ & $66.22 \mathrm{~dB}$ & $56.02 \mathrm{~dB}$ & $-10.2 \mathrm{~dB}$ & B & \multirow{2}{*}{$16.66 \%$} & $122.2 \mathrm{~Hz}$ \\
\hline 6 & T_1 & $75.11 \mathrm{~dB}$ & $60.01 \mathrm{~dB}$ & $-15.1 \mathrm{~dB}$ & B & & $163.1 \mathrm{~Hz}$ \\
\hline 7 & T_8 & $72.01 \mathrm{~dB}$ & $69.28 \mathrm{~dB}$ & $-2.73 \mathrm{~dB}$ & $\mathrm{AB}$ & \multirow{3}{*}{$25 \%$} & $103.6 \mathrm{~Hz}$ \\
\hline 8 & T_6 & $64.03 \mathrm{~dB}$ & $62.04 \mathrm{~dB}$ & $-1.99 \mathrm{~dB}$ & $\mathrm{AB}$ & & $199 \mathrm{~Hz}$ \\
\hline 9 & T_2 & $67.11 \mathrm{~dB}$ & $65.55 \mathrm{~dB}$ & $-1.56 \mathrm{~dB}$ & $\mathrm{AB}$ & & $163.2 \mathrm{~Hz}$ \\
\hline 10 & T_3 & $61.22 \mathrm{~dB}$ & $67.88 \mathrm{~dB}$ & $6.66 \mathrm{~dB}$ & \multirow{2}{*}{ Adapt $50-69 \%$ RP } & \multirow{2}{*}{$16.66 \%$} & $122.7 \mathrm{~Hz}$ \\
\hline 11 & T_4 & $65.04 \mathrm{~dB}$ & $73.05 \mathrm{~dB}$ & $8.01 \mathrm{~dB}$ & & & $192.4 \mathrm{~Hz}$ \\
\hline 12 & T_11 & $59.21 \mathrm{~dB}$ & $68.82 \mathrm{~dB}$ & $9.61 \mathrm{~dB}$ & Adapt $70-90 \%$ RP & $8.33 \%-$ & $111.3 \mathrm{~Hz}$ \\
\hline
\end{tabular}

ĐóI CHIÉU HIẸंU SÓ CƯờnG Đọ̉ ĐîNH 2 ÂM TIÉT TỪ CHORALE GIỮA CPAC VÀ 12 MKS

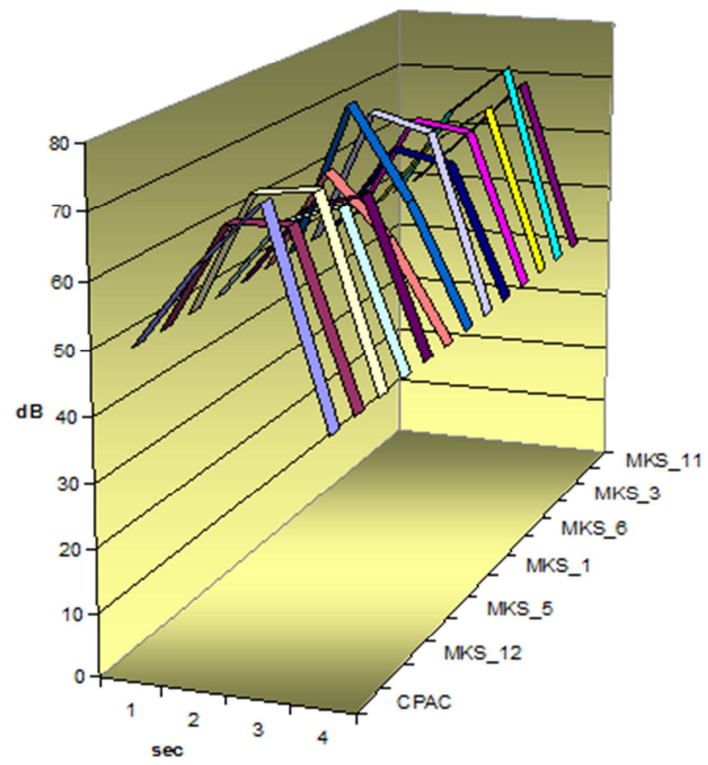




\subsubsection{Types of English Stress Mistake}

From the phonetic experiment above, three types of English stress mistakes have been recognized

Type 1: Rhythmic error (A)

Right stress placement but nearly the same force for the two syllables, not adapt the Rhythmic Pattern $\{\mathrm{F}=[\mathrm{S} \mathrm{W}]\}$.

The two IS (MKS) adapted $50-69 \%$ RP (CPAC), equal to
$16.66 \%$ since the intensity difference (ID) between the 2 syllable peaks of IS $3=67.88 \mathrm{~dB}-61.22 \mathrm{~dB}=6.66 \mathrm{~dB}$ and ID between the 2 syllable of IS $4=73.05 \mathrm{~dB}-65.04 \mathrm{~dB}=8.01 \mathrm{~dB}$. Therefore, there was no mistake of stress placement. However, this intensity difference can not lead to one strong syllable and one weak syllable of the Rhythmic pattern $\{\mathrm{F}=[\mathrm{S} \mathrm{W}]\}$. Therefore, this is the illustration for the Rhythmic error (A).

\section{ĐÓI CHIÉU HIỊ̂U SÓ CƯỜNG ĐỌ 2 ĐINH ẢM TIÉT GIỮA CPAC VÀ MKS 3, 4}

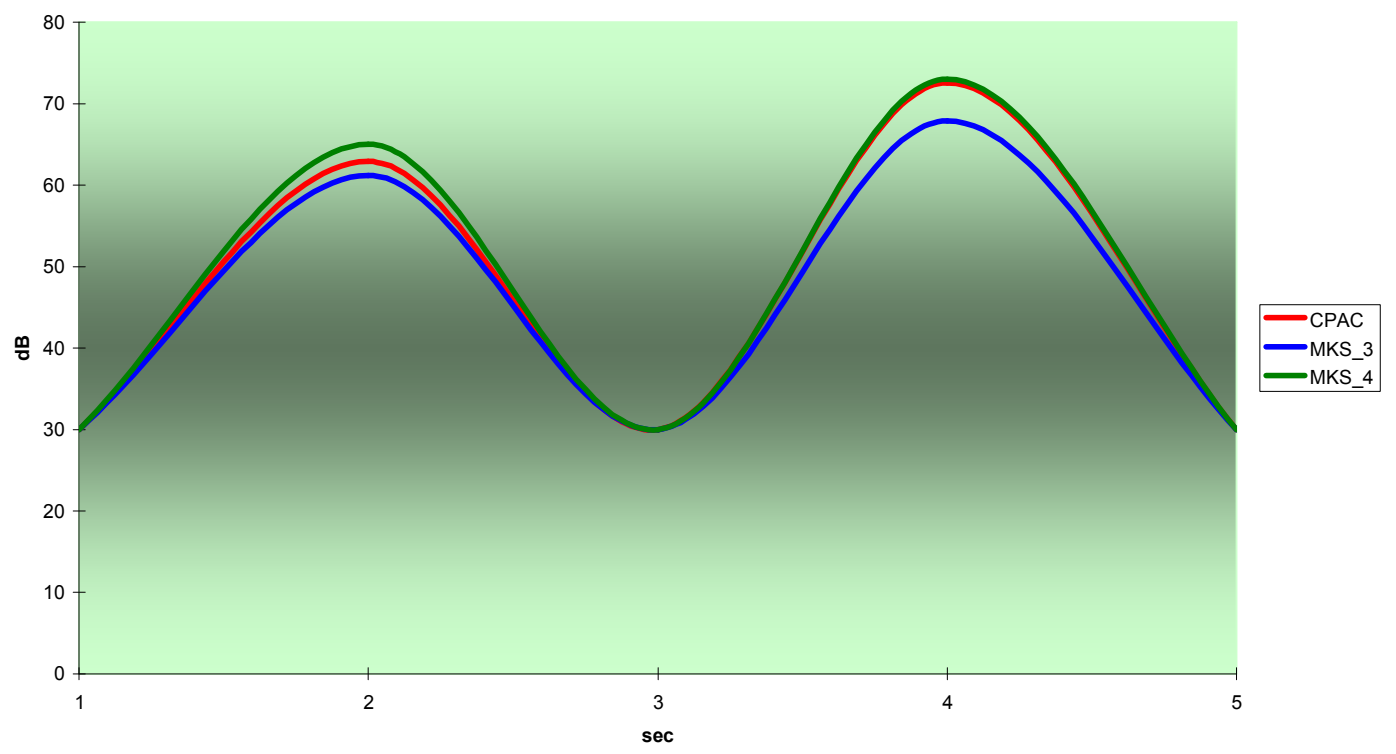

Figure 3. The intensity difference between the 2 syllable peaks of the word [chorale] between RP and IS_3,4.

Type 2: Wrong placement of stress (B)

Gaining the percentage $16.66 \%$ is the two investigated samples having the intensity difference between the 2 syllable peaks from $10 \mathrm{p}$ to adapt the Rhythmic pattern $\{\mathrm{F}=[\mathrm{S} \mathrm{W}]\}$. However, the intensity difference between the two syllable peaks of IS $1=60.01 \mathrm{~dB}-75.11 \mathrm{~dB}=-15.1 \mathrm{~dB}$ and between the two syllable peaks of IS_10 $=56.02 \mathrm{~dB}-66,22 \mathrm{~dB}=-10.2$ $\mathrm{dB}$, to illustrate that the two investigated samples place stress on the 1 st syllable to make the stress placement mistake (B).

\section{ĐóI CHIÉU HIẸU SÓ CƯờNG ĐỌ 2 ĐINH ẢM TIÉT GIỮA CPAC VÀ MKS 1, 10}

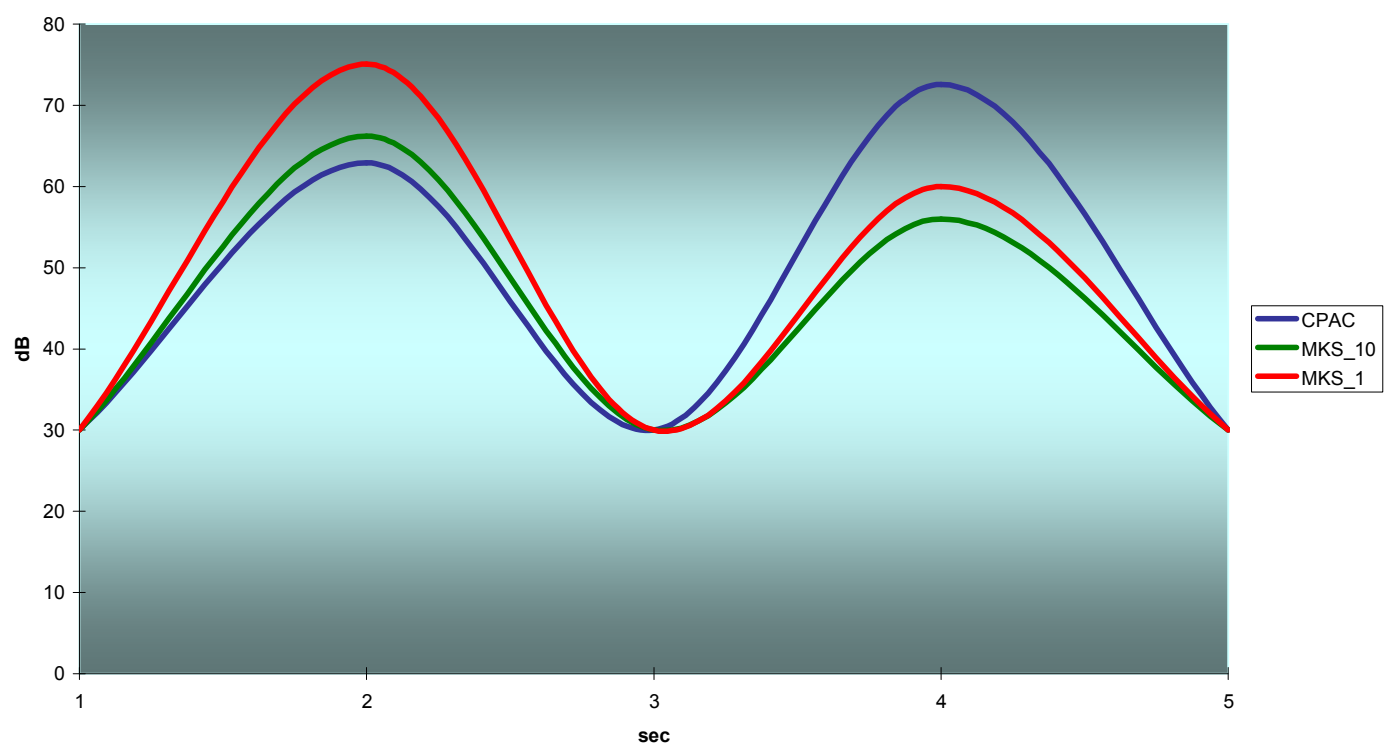

Figure 4. The intensity difference between the 2 syllable peaks of the word [chor ale] between RP and IS_1,10. 
Type 3: The combination of type 1 and type 2: $(A+B)$

Rhythmic error (A) and Wrong placement of stress (B).

One more mistake type is the combination of the Rhythmic error (A) and the wrong placement of stress (B), having 25\%, since the intensity difference between the two syllable peaks of IS $8=69.28 \mathrm{~dB}-72.01 \mathrm{~dB}=-2.73 \mathrm{~dB}$, IS $6=62.04 \mathrm{~dB}-$ $64.03 \mathrm{~dB}=,-1.99 \mathrm{~dB}$ HSCĐ and T $2=65.55 \overline{\mathrm{dB}}-67.11 \mathrm{~dB}=$ -
$1.56 \mathrm{~dB}$ to illustrate the wrong placement of stress while placing stress at the 1 st syllable. Moreover, the intensity differences $<3$, showing the unablility of adapting the Rhythmic Pattern $\{\mathrm{F}=[\mathrm{S} \mathrm{W}]\}$, to compare with the intensity difference between the two syllable peak of $\mathrm{RP}==72.60 \mathrm{~dB}$ $62.90 \mathrm{~dB}=9.70 \mathrm{~dB}>5$.

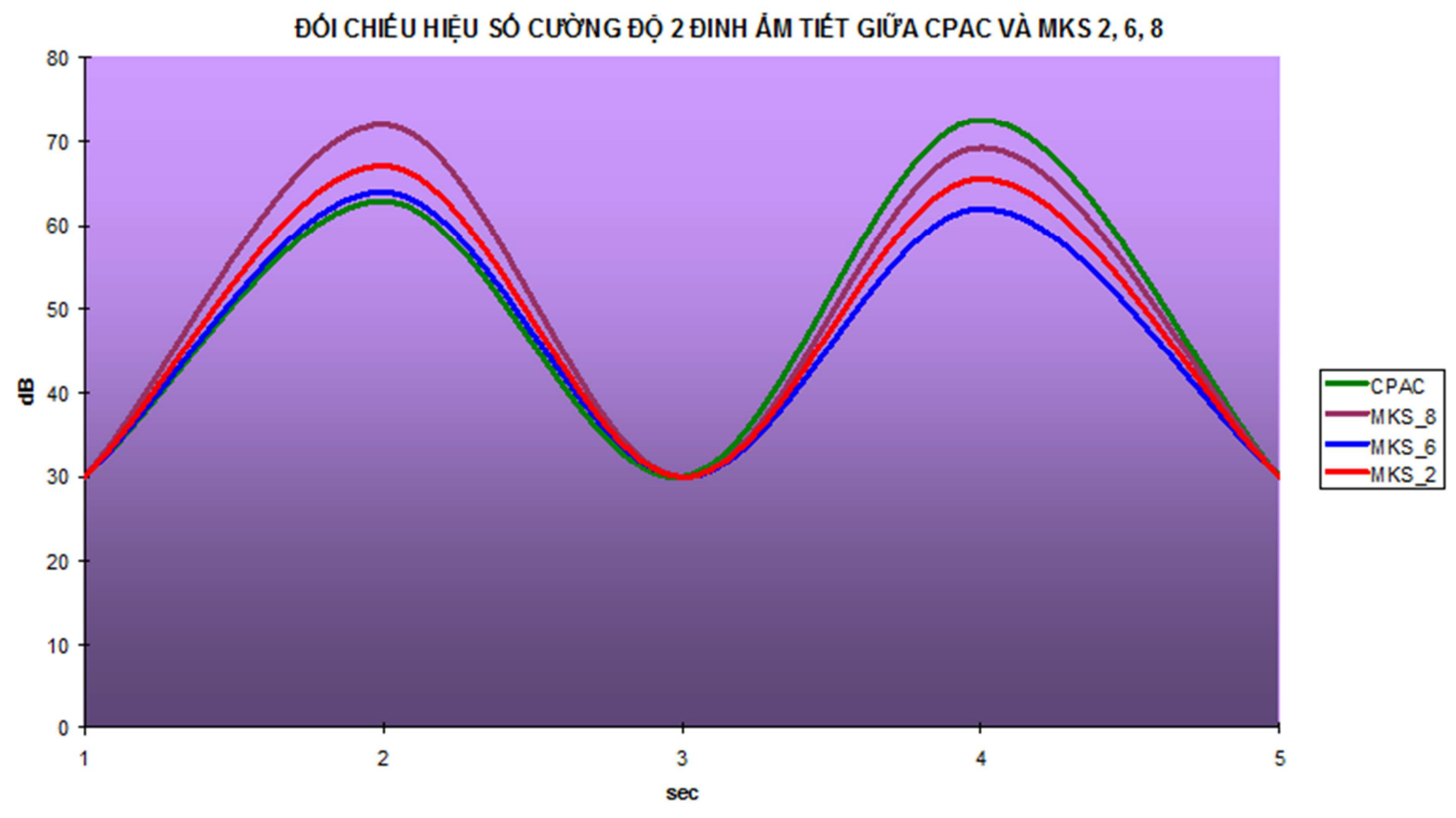

Figure 5. The intensity difference between the 2 syllable peaks of the word [chorale] between RP and IS_2,6,8.

\subsubsection{Solution}

Rhythm is so important to language with multi-syllabic words that children have to learn the rhythm of their L1 very early in life [[12]]. By the time they reach the age of one, that rhythm is deeply familiar to them, and they will unconsciously apply it to any L2 that they learn (Aoyama et al. 2007). Since English learners will be predisposed to use the rhythm of their L1, it is highly important that they make consciously aware of the English system of rhythm. The basic unit of English rhythm is the syllable. A syllable is most simply explained as something with a vowel sound at its center. And while the number of syllables in a word is usually obvious to a native speaker of English, learners being accustomed to different phonological rules may not hear the syllable divisions in the same way. Since this seriously affects both intelligibility and listening comprehension, time must be spent training students' ears to notice the number of syllables in the words they learn.

Precisely, Vietnamese rhythmic pattern does not have the differences in intensity between stressed and unstressed syllables; on the contrary, English rhythmic pattern has differences in intensity (of course also in pitch and vowel duration). As a result, to be affected by this mother-tongue characteristics, Vietnamese students are not aware of the importance of syllable weight, shown through intensity, the main cue to identify English word stress, which decide the ability to catch the accurate information based on the main syllable of a word, which is not only the stressed syllable but also the tonic syllable in a tone unit. Therefore, teachers should spend more time training students how to count the number of syllable in a word, identify the syllable weight (strong syllable/ heavy syllable $=$ stressed syllable and weak syllable/ light syllable $=$ unstressed syllable) to be able to follow the English rhythmic pattern. Therefore, from the conclusion above, the English stress rules for English multi-syllabic words, are systemized, as follows [[19]]. 


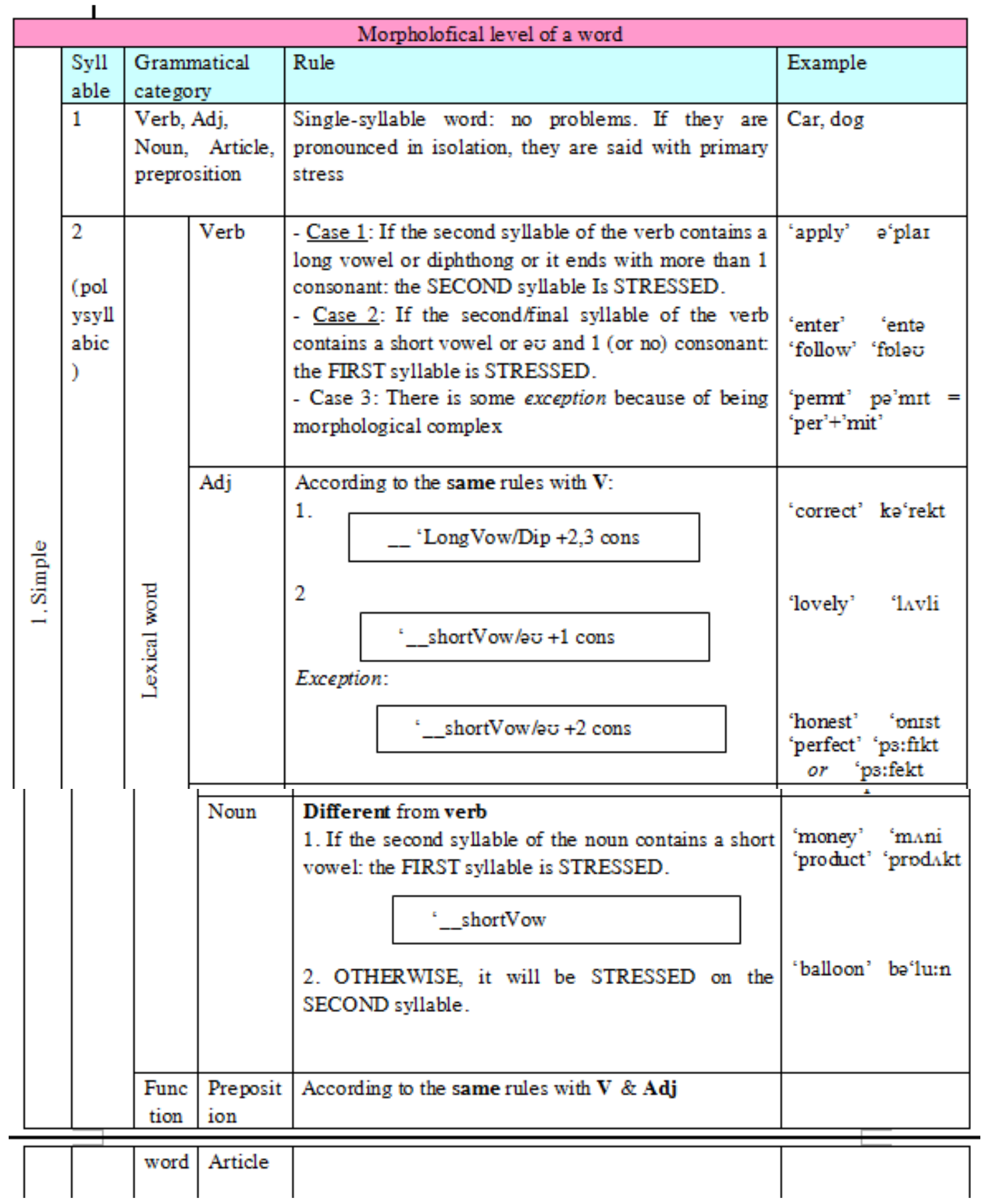




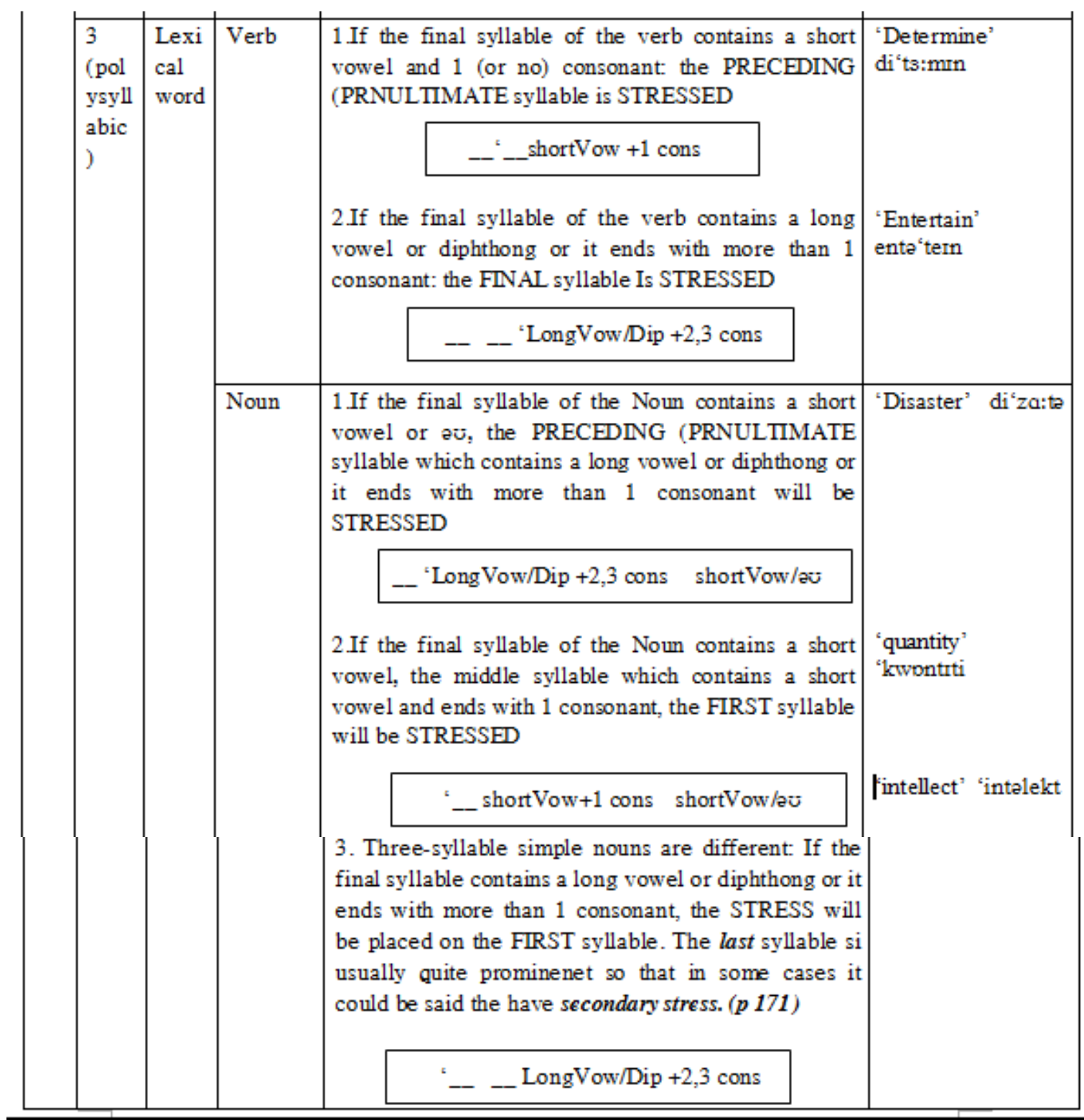

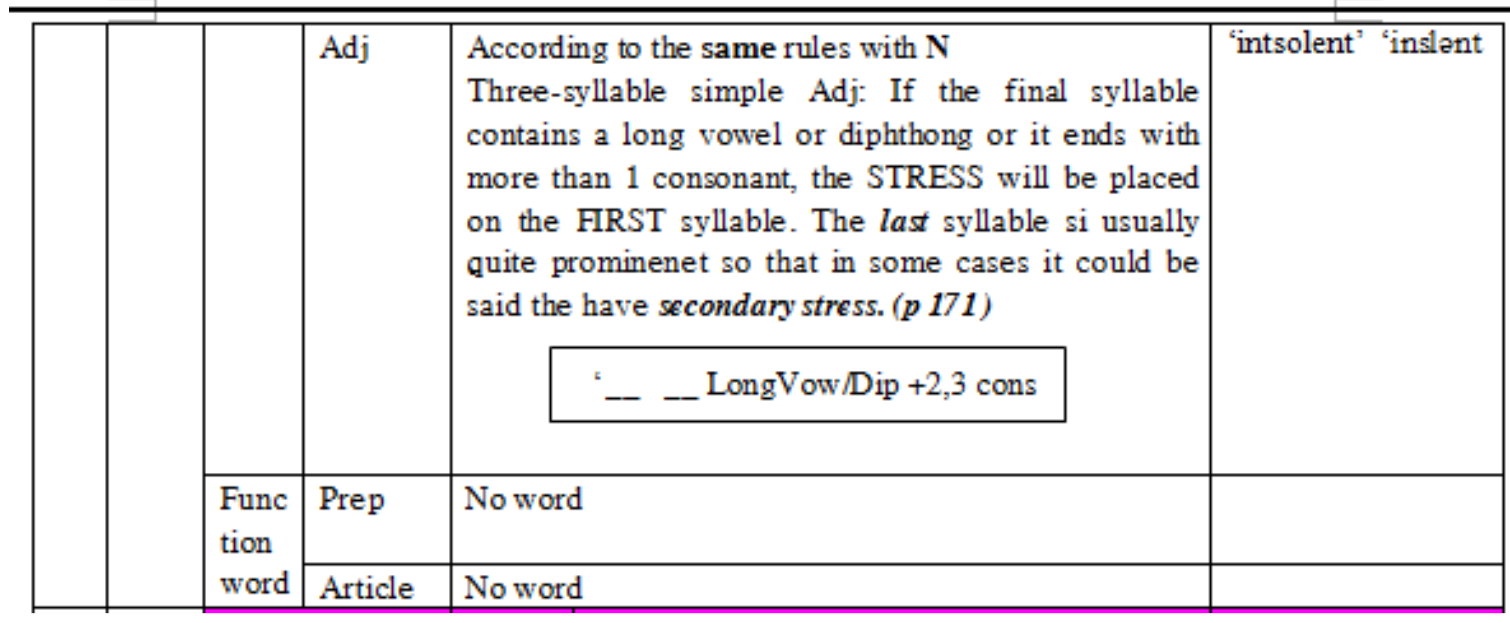




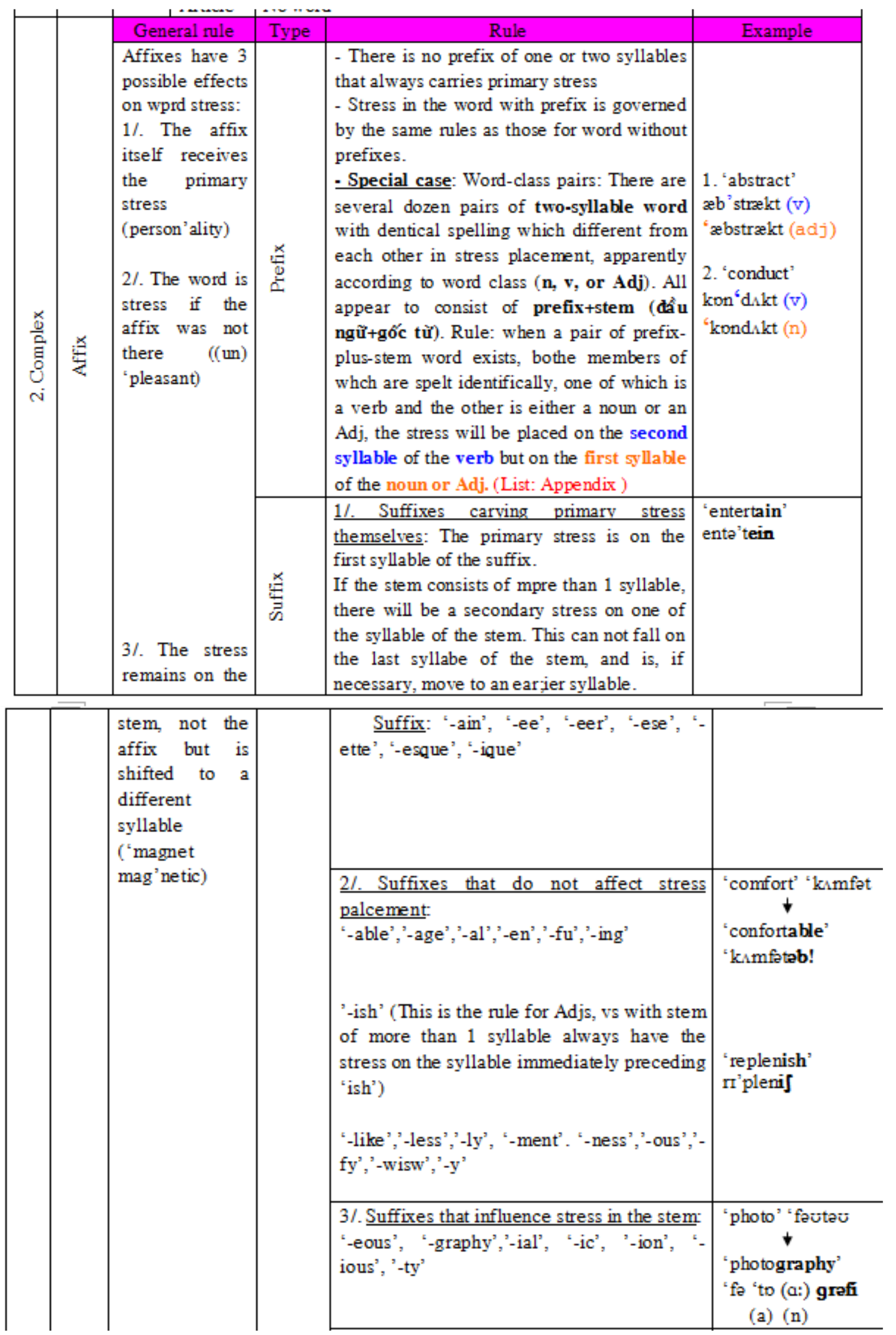




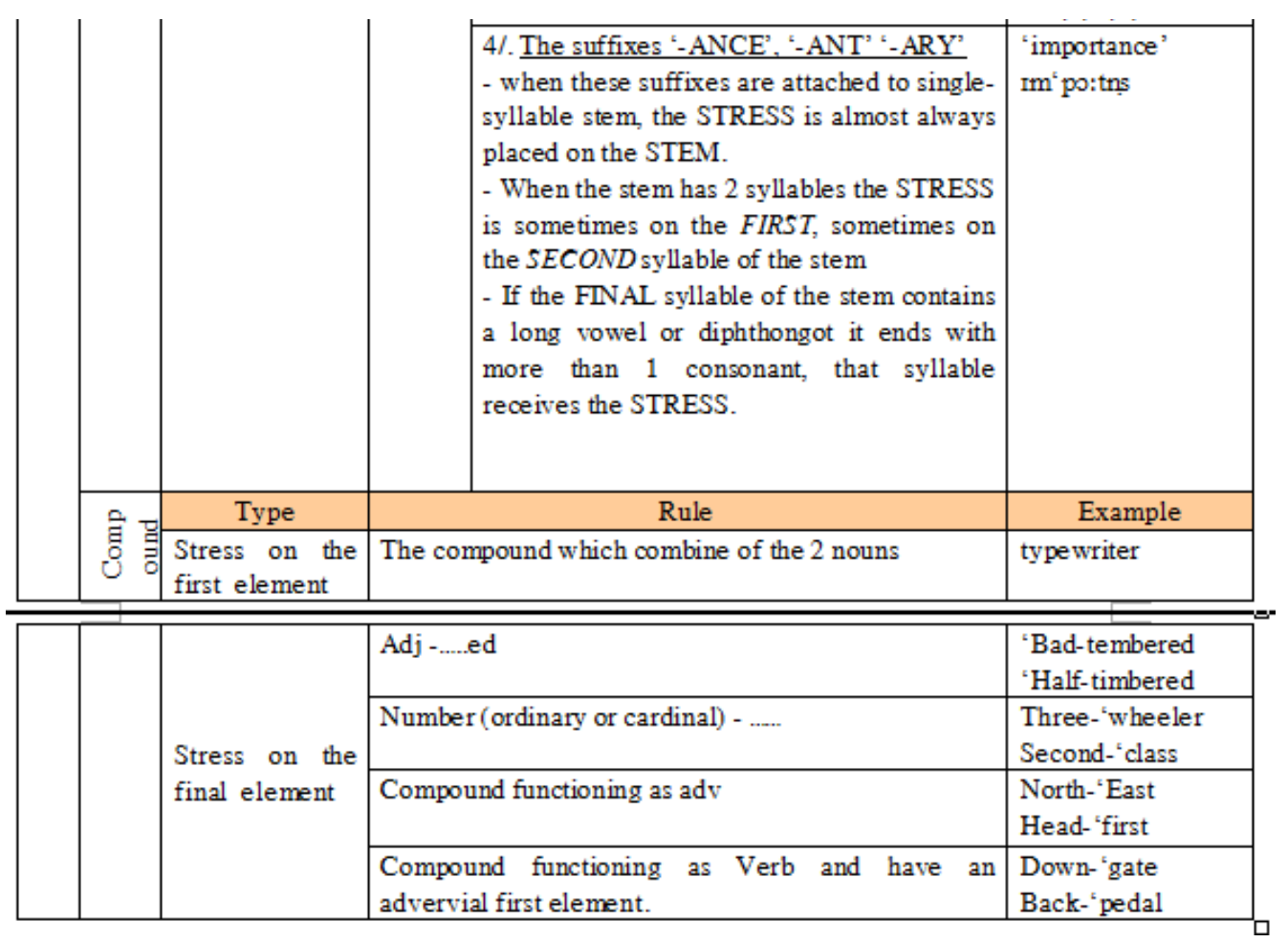

Figure 6. English stress rules.

From the table of complicated stress rules above, a brief summary of key points for recognizing the places of stress in English words has been consolidated based on rhythm, melody, word types (simple, compound, complex), word class (N, V, Adj), and the number of syllable with or without affix, as well as syllable structure based on the Rhythmic patterns [[18]]. The foundation of English rhythmic patterns is the existence of the 2 types of syllables: light syllable and heavy syllable, called Trochee: Trochee: Trochaic foot with 1 long syllable (= heavy syllable $=$ strong syllable $=$ stressed syllable) and 1 short syllable (= light syllable $=$ unstressed syllable). Strong syllable is a syllable with initial consonant and a complicated rhyme which consists of final consonant and a short vowel or long vowel or a diphthong as nuclei [[18], p. 125]. On the contrary, a light syllable contains a vowel in the rhyme, with or without onset but no coda, as the first syllable in the word report, about [[18], p. 85].

Therefore, based on the distinction between heavy syllable and light syllable, word class, and the number of syllable with or without affix, as well as syllable structure based on the Rhythmic patterns, the characteristics of stressed and unstressed syllable have been simply systemized as follows: [[19], p. 119124].

- The main characteristics of the unstressed syllable: Syllable containing schwa or short vowel or diphthong $/ \Perp \bigcup /$, ending with not more than 1 consonant.

- The main characteristics of the stressed syllable: the syllable containing long vowel or diphthong or ending with more than 1 consonant.

- Especially, no initial syllable in a verb and no final syllable in a noun, as well as no prefix are stressed.

\section{(i). Simple Words: Multi-syllabic Words Without Affix}

(a). Simple disyllabic words: Syllable containing long vowel or diphthong or ending with more than 1 consonant is stressed. Ex: photo [' $f \cup t U]$, chorale [k ' $\mathrm{r}=\mathrm{s}: 1]$, comfort [' $\mathrm{k}$ ' $\mathrm{mft}$ ].

(b). Simple trisyllabic words, with some special points

- Trisyllabic verb: No initial syllable is stressed. Therefore, syllable containing long vowel or diphthong or ending with more than 1 consonant is stressed. Ex: entertain /[ent 'tein].

- Trisyllabicnoun: No final syllable is stressed. Therefore, the syllable containing long vowel or diphthong orending with more than 1 consonant is stressed. Ex: character

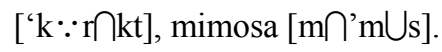

\begin{tabular}{|c|c|c|c|}
\hline $\mathrm{N}$ & Unstressed syllable & Situation & Stressed \\
\hline 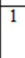 & Syllables containing schwa $(\partial \quad \mathrm{I}$ U) & $\begin{array}{l}\text { The second syllable in the } 2 \\
\text { syllabic noun }\end{array}$ & \multirow{4}{*}{$\begin{array}{l}\text { Initial } \\
\text { Syllable }\end{array}$} \\
\hline 2 & $\begin{array}{l}\text { Syllables containing schwa end with not } \\
\text { more than } 1 \text { consonant }\end{array}$ & $\begin{array}{l}\text { The middle syllable in the } 3 \\
\text { syllabic noun }\end{array}$ & \\
\hline 3 & $\begin{array}{l}\text { Syllables containing short vowel, or schwa, } \\
\text { or diphthong /au/ }\end{array}$ & $\begin{array}{l}\text { The final syllable in the } 3 \text { syllabic } \\
\text { noun }\end{array}$ & \\
\hline 4 & $\begin{array}{l}\text { Syllables containing schwa or diphthong } \\
/ \diamond \mathrm{v} / \text {, end with not more than } 1 \text { consonant }\end{array}$ & $\begin{array}{l}\text { The second syllable in the } 2 \\
\text { syllabic noun and Verb }\end{array}$ & \\
\hline \multicolumn{2}{|r|}{ Stressed syllable } & \multicolumn{2}{|l|}{ Position in word } \\
\hline \multirow[t]{2}{*}{1} & \multirow{2}{*}{$\begin{array}{l}\text { Syllables containing long vowel or diphthong } \\
\text { or end with more than } 1 \text { consonant }\end{array}$} & \multirow{2}{*}{\multicolumn{2}{|c|}{ The second syllable in the 2 syllabic Adj and Verb }} \\
\hline & & & \\
\hline \multicolumn{2}{|r|}{ Exception: Unstress syllable } & Situation & Stressed \\
\hline 1 & $\begin{array}{l}\text { yllables containing long vowel or diphthong or } \\
\text { end with more than } 1 \text { consonant }\end{array}$ & $\begin{array}{l}\text { The final syllable in the } 3 \\
\text { syllabic Adj and Noun }\end{array}$ & \multirow{3}{*}{ Initial syllable } \\
\hline 2 & $\begin{array}{l}\text { Syllables containing schwa or diphthong } / 2 \mathrm{u} / \text {, } \\
\text { end with } 2 \text { consonants }\end{array}$ & $\begin{array}{l}\text { The second syllable in the } 2 \\
\text { syllabic Verb }\end{array}$ & \\
\hline 3 & Syllables end with more than 1 consonant & $\begin{array}{l}\text { The second syllable in the } 2 \\
\text { syllabic Adj }\end{array}$ & \\
\hline
\end{tabular}

Figure 7. The main characteristics of the stressed and unstressed syllables in simple words. 


\section{(ii). Complex Word: Multi-syllabic Word with Affix}

(a). Prefix

- There is no prefix of one or two syllables that always carries primary stress.

- Stress in the word with prefix is governed by the same rules as those for words without prefixes.

- Word-class pairs: The stress will be placed on the second syllable of the verb but on the first syllable of the noun or Adjective.

\begin{tabular}{|l|l|l|l|}
\hline No & \multicolumn{2}{|c|}{ PREFIX: The stress characteristiecs of prefix } & \multicolumn{1}{c|}{ Brief } \\
\hline 1 & \multicolumn{2}{|c|}{$\begin{array}{l}\text { There is no prefix of one or two syllables that always } \\
\text { carries primary stress }\end{array}$} & Prefix iss unstressed \\
\hline 2 & $\begin{array}{l}\text { Stress in the word with prefix is governed by the same } \\
\text { rules as those for word without prefixes }\end{array}$ & $\begin{array}{l}\text { Prefix does not affect sressed } \\
\text { syllable }\end{array}$ \\
\hline 3 & $\begin{array}{l}\text { Word-class pairs } \\
\text { Ex: 'abstract' }\end{array}$ & Prefix + 'Root & Verb æob 'strækt \\
\cline { 3 - 4 } & 'Prefix + Root & Adj 'æbstrækt \\
\hline
\end{tabular}

Figure 8. The stress characteristics of prefix.

(b). Suffix

- Suffixes carrying primary stress themselves: (-ain, -ee, -eer, -ese, -ette, -esque, -ique). Ex: entertain /ent 'tein/;

- Suffixes that do not affect stress placement: ('-able', '-age','-al','-en','-fu', '-ing').

- The stress on the syllable immediately preceding the suffix:

('ish'“-like', '-less','-ly', '-ment'.'-ness','-ous', '-fy','-wisw ','-y')

- Suffixes that influence stress in the stem: ('-eous', '-graphy','-ial', '-ic', '-ion', '-ious', '-ty')

\begin{tabular}{|c|c|c|}
\hline No & SUFFIX: The stress characteristiecs of suffix & Suffix \\
\hline 1 & Suffixes carying primary stress themselves & '-ain', '-ee', '-eer', '-ese', '-ette', '-esque', '-ique' \\
\hline 2 & Suffixes that do not affect stress palcement & '-able,',-age','-all,',-en','-ful','-ing' \\
\hline 3 & $\begin{array}{l}\text { the stress on the syllable immediately } \\
\text { preceding the suffix }\end{array}$ & $\begin{array}{l}\text { 'ish',-like','-less', '-ly', '-ment', '-ness', '-ous','- } \\
\text { fy,',-wisw','-y' }\end{array}$ \\
\hline 4 & Suffixes that influence stress in the stem: & '-eous', '-graphy','-ial', '-ic', '-ion', '-ious', '-ty' \\
\hline
\end{tabular}

Figure 9. The stress characteristics of suffix.

\section{(iii). Compound Word: with 2 Roots}

In the compound with 2 Nouns, The $1^{\text {st }}$ syllable is stressed. In the other cases, the 2 nd syllable is stressed.

\begin{tabular}{|l|l|}
\hline No & \multicolumn{1}{|c|}{ Stressed syllable } \\
\hline 1 & The $1^{\text {st }}$ syllable is stressed: Compound with 2 Nouns \\
\hline 2 & The $2^{\text {nd }}$ syllable is stressed: The other cases \\
\hline
\end{tabular}

Figure 10. Characteristics of the stressed syllable in compound words.

\section{Conclusion}

In short, English word stress can be recognized by the following criteria:

- Syllable structure characteristics: Only strong syllables are stressed. Strong syllables (sometimes called heavy syllable) is a syllable which has a complex rhyme, with two cases. First, a heavy syllable may have a short vowel, but one or more coda consonants. Second, it may have a branching nucleus, consisting of a long vowel or diphthong; such a syllable will be heavy whether it also has a bled coda;

- Word structure: Simple words is based on the syllable structure characteristics to recognize stress. Complex word: no prefix is stressed; Suffixes are stressed and unstressed, change stressed syllable or not. Compound words with 2 nouns are stressed on the first syllable; otherwise, the second syllable is stressed;

- Rhythmic pattern Stress-timed language, with the rhythmic pattern based on the regular repetition of the stressed syllables: Pattern $\{\mathrm{F}=[\mathrm{S} \mathrm{W}]\},(\mathrm{F}=$ Foot, $\mathrm{S}=$ strong, $\mathrm{W}=$ weak);

- Intensity: English word stress can be mainly recognized by intensity; therefore, stressed syllable is pronounced with much force, also longer (duration), and higher (pitch).

Remembering the four criteria above helps students prevent from the three main types of stress errors: (1). Rhythmic error (no Rhythmic Pattern $\{\mathrm{F}=[\mathrm{S} \mathrm{W}]\}$ ); (2). Stress placement error; and (3). The combination of Rhythmic and Placement error.

\section{References}

[1] Anderson, John M.; and Ewen, Colin J. (1987). Principles of dependency phonology. Cambridge University Press.

[2] Aoyama, K. \& S. Guion. (2007). Prosody in second language acquisition. Acoustic analyses of duration and FO range. In O.-S. Bohn \& M. Munro, eds. Language experience in second language speech learning. In honor of James Emil Flege, John Benjamins: 281-297.

[3] Brentari, Diane. (1998). A prosodic model of sign language phonology. Cambridge, MA: MIT Press.

[4] Nguyễn Tài Cẩn. (1997). Giáotrìnhlịchsửngữâmtiếng Việt. Nxb Giáodục.

[5] Chomsky N and Halle M. (1968). The sound pattern of English. New York: Harper \& Row.

[6] Tran Thi Thanh Dieu. (2015). A case study of solutions to some stress mistakes made by Vietnamese students - a phonetic experimental research International Journal of Language. Vol. 3, No. 2, 2015. pp. 52-60. ISSN: 2330-0221.

[7] Clements, George N. (1985). The geometry of phonological features. Phonology Yearbook, 2, 225-252.

[8] Clements, George N.; and Samuel J. Keyser. (1983). CV phonology: A generative theory of the syllable. Linguistic inquiry monographs (No. 9). Cambridge, MA: MIT Press. ISBN 0-262-53047-3 ISBN 0-262-03098-5.

[9] De Lacy, Paul. (2007). The Cambridge Handbook of Phonology. Cambridge University Press. ISBN 0-521-84879-2 (hbk).

[10] Nguyễn Công Đức, Nguyễn Hữu Chương. (2004). Từvựngtiếng Việt. Tủsách Đạihọc Khoahọc Xãhộivà Nhânvăn. 
[11] Nguyễn Thiện Giáp. (2009). Cácphươngphápnghiêncứungônngữ. Nxb Giáodục.

[12] Goldsmith, John A. (1995). "Phonological Theory". in John A. Goldsmith. The Handbook of Phonological Theory. Blackwell Handbooks in Linguistics. Blackwell Publishers.

[13] Goldsmith, John A. (1979). The aims of autosegmental phonology. In D. A. Dinnsen (Ed.), Current approaches to phonological theory. Bloomington: Indiana University Press.

[14] Cao XuânHạo. (2006). TiếngViệt, mấyvấnđềNgữâm, Ngữpháp, Ngữnghĩa. NxbKhoahọcXãhội.

[15] NguyễnQuangHồng. (2002). Âmtiếtvàloạihìnhngônngữ. Nxb Đạihọc Quốcgia HàNội.

[16] Jones D. 1909/ (2002). The pronunciation of English. Cambridge University Press.

[17] Ladefoged, Peter. (2001). A course in phonetics (4th ed.). Boston: Heinle \& Heinle, Thomson Learning.

[18] McMahon A. (1988). An introduction to English phonology. Edinburgh University Press.

[19] Roach, P. (1998). English Phonetics and Phonology. The Youth Press, Vietnam.

[20] Spencer, A. (1991). Morphological Theory. Cambridge University Press.

[21] Stump, G, T. (2001). Inflectional Morphology - A theory of Paradigm Structure. Cambridge University Press.

[22] SEAMEO Regional Language Center. (2003). Research
Methodology. Singapore: SEAMEO Regional Language Center.

[23] Griffee D. T. \&Nunan D. (1997). Classroom Teachers and Classroom research. Tokyo, Japan: The Japan Association for Language Teaching.

[24] Hadley G. (2003). Action Research in Action. Singapore: SEAMEO Regional Language Center.

[25] Hatch E and Lazaraton A, University of California. (1991). The Research Manual Design and Statistics for Applied Linguistics. Boston: Heinle \& Heinle Publishers A Division of Wadsworth, Inc Boston, Massachusetts 02116.

[26] Fry D. B. (1955). Duration and intensity as physical correlates of linguistic stress. J. Acoust. Soc. Am. 27, 765-768. doi: 10.1121/1.1908022.

[27] Fry D. B. (1958). Experiments in the perception of stress. Lang Speech 1, 126-152.

[28] Fry D. B. (1965). The dependence of stress judgments on vowel formant structure. in Proceedings of the 5th International Congress of Phonetics Sciences, eds. Zwerner X., and Bethge W., Karger: Basel, pp. 306-311.

[29] Đinh Lê Thư, Nguyễn Văn Huệ. (1998). Cơcấungữâmtiếng Việt. Nxb Giáodục.

[30] Đòan Thiện Thuật. (1980). Ngữâmtiếng Việt. Nxb Đạihọcvà Trunghọcchuyênnghiệp.

[31] Lê Quang Thiêm. (2004). Nghiêncứuđốichiếucácngônngữ. Nxb Đạihọc Quốcgia HàNội. 